\title{
The multilingual person in society ${ }^{1}$
}

\section{Carol A. Puhl}

Half of the people of the world speak two or more languages. This paper explores the language choice from the perspective of the multilingual person. It distinguishes between the individual and private (inner world) needs of the L1 speaker and the socio-cultural (outer world) needs of the L2 speaker. It examines the multilingual situation in USA and compares it with the situation in Southern Africa, highlighting both similarities and differences.

Die helfte van die mense in die wêreld praat twee of meer tale. Hierdie artikel ondersoek die taalkeuse vanuit die perspektief van die veeltalige persoon. Daar word onderskei tussen die individuele, private (binnewêreld) behoeftes van die moedertaalspreker en die sosio-kulturele (buitewêreld) behoeftes van die tweedetaalspreker. Die veeltalige situasie in die VSA word ondersoek en vergelyk met die situasie in Suidelike Afrika, met spesiale aandag aan ooreenkomste en verskille.

The fact that there are 3000 to 4000 languages spoken in the world today, along with the fact that there are about 150 countries indicates how multilingual most societies are. ${ }^{2}$ Indeed, multilingualism is the norm; it is estimated that about half of the people in the world speak two or more languages (Grosjean, 1982). With over 1000 languages spoken in Africa, Bokamba (1983) states that it may be the most multilingual continent, with more languages per capita than anywhere else. This multilingualism indicates that languages are in contact, and contact often includes conflict, which is expressed, among other ways, in matters of language. Languages are used to show power, to consolidate power, and to perpetuate power. Languages are used to resist power. Languages are used to develop and maintain self-identity of both persons and societies. Languages are used as a means to a job, to economic advantage. Awareness of such forces underlying language choice allows us to see beyond the view of language as expressive; we human beings are always expressive in the context of others, and always to achieve some non-linguistic goal. Language both connects and divides us as we in some way decide.

By understanding these aspects we can make more informed choices regarding language policy, which remains a critical issue in many places in the world today. These choices at a national level imply choices about who gets recog- 
nition, as well as more pragmatic ones such as language requirements for employment, and how a country's money is spent on language-related issues. ${ }^{3}$ Surely the relative place of languages in the educational system along with development of materials and training of teachers are loaded with a nation's interests. Understanding the dynamics of the multilingual person in society can illuminate language-related choices for both nations and educators, and can help educators who in any way work with teaching an L2 or teaching in an L2 to gain a fuller insight into what is happening to the people, usually young people, in their classes. These choices can be far-reaching in their effects. While language choice has much to do with a country's identity, it also is deeply related to the individual. What does it take for a person to become bilingual or multiingual? Why does a person do it? What changes in the person take place from becoming bilingual? What societal factors impinge?

Numerous works could be cited to show that a great deal of attention has been given to language policy (for instance, see Paulston, 1988, for a book devoted to international bilingualism), and linguistic matters have also been studied extensively (for instance, see Kachru, 1983, for a book devoted to English language change worldwide). It is the purpose of this paper to explore language choice from the perspective of the bilingual or multilingual person. This viewpoint is rarely considered, even though questions have been raised by Weinreich (1974), Haugen $(1956,1969)$, in Kirschner and Stephens (1987) and Grosjean (1982), and occasional studies do appear, such as that of Kirschner and Stephens (1987), who studied the perceptions of bilinguals about themselves as bilinguals.

To see from the perspective of the bilingual or multilingual person, it is helpful to distinguish an inner and an outer world, similar to the distinction made by Weinreich (1974) into individual and socio-cultural. The inner world is used to refer to thoughts, feelings, attitudes, motives, whatever goes on inside a person, and the outer world is used to refer to realities external to a person, such as events and the behaviour of others. However, these two worlds are inseparable in that outer realities are something that people tend to internalise as well as influence. The bipolar terms inner and outer should be seen as ends of a continuum, with the dichotomy only as a convenient way to explore what the multilingual person faces.

Let us specify two general assumptions upon which the arguments in this paper are based. First, the L1 is the language of deep and primal human identity. The $\mathrm{L} 1$ roots us and gives us psychological comfort. Its main value is in the inner world. Second, the L2 or additional language extends us, giving us more points of contact, power, and achievement. Its main value is in the outer world. The more familiar view is that of the outer world, so let us start with that one, proceed to the inner world, examine the language situation in the United States as a case study for relevance it might hold for Southern Africa, 
and conclude with some observations which may be useful to the multilingual person in society.

A few societies are greatly monolingual, such as West Germany and Japan (Grosjean, 1982). They speak basically one language and thrive with one main culture. Still, one can find small groups there from other countries, but those persons do not constitute powerful societal groups. The Ainu, Koreans, and Chinese total less than $1 \%$ of Japan's population, and immigrant workers who stayed in West Germany also total less than $1 \%$ of the population.

Most societies are multilingual to some significant degree, in that they include minority groups which speak different languages. Implicit in the language difference is a culture difference, for language and the culture it expresses are inseparable. These differences are heightened by socio-economic, ethnic, or racial differences as well. It is usual and indeed practically inevitable that such groups within a larger society differ with respect to the relative status they attain and the degree of power they hold. This differential can be observed generally speaking in the types of work done by group members, the money they control, and the living areas in which they cluster. A nearly isolated exception to different prestige of languages in contact is Switzerland, a country of four official languages, where speakers of German and speakers of Italian hold each other's language in high esteem (Grosjean, 1982).

That language and culture are inseparable is not usually explicitly recognized, so let us explore it further. Let us look at culture as a way of life, a series of interconnected beliefs, behaviours, and values characteristic of a certain group. The language that group uses to communicate encodes and perpetuates these beliefs, behaviours, and values, thus binding the group members together. Any significant change in the culture will be accompanied by its own special vocabulary, which may not necessarily be new words but more likely existing words which are used in a new way and/or to which new meanings are attached.

An example of the language-culture connection in English is the new cultural consciousness raised by the women's movement. In this context "woman" means a female capable of taking care of herself, her life and her own decisions; the connotations are of strength and autonomy. "Girl" in this context means a young female, too young to be self-directed so she must be taken care of by someone else, with connotations of childishness and dependence. "Lady" indicates a female preoccupied with refined but unimportant details, with connotations of irrelevance and superficiality. Nowadays in the U.S. to say "the girl in the office" to refer to a secretary, for example, is regarded as denigrating and may well be met with hostility from "the girl". The use of "man" to represent both men and women is now seen as sexist (Martyna, 1983), especially in the light of evidence from research that psychologically, when the word was decoded in people's minds, its meaning was much more heavily male; it served in effect to keep women invisible (Miller and Swift, 1976). Indeed, 
invisibility and lesser status are systematically accorded to women by the vocabulary and syntax of the English language in general. The changes in cultural consciousness are slowly being encoded into the language, and the language will then serve to reflect them and carry them on.

Another example of the language-culture connection comes from the foreign student from China studying in the U.S. who said he does his arithmetic in Chinese and his calculus in English (Kolers, 1968). The language in which he encoded his experiences remains comfortably bound to the content, or culture. This is not to say that the student cannot do arithmetic in English or calculus in Chinese, only that a translation process is then required.

Whether language affects reality (culture) or whether reality affects language is another interesting issue, first studied systematically by two researchers who gave it their names, the Sapir-Whorf Hypothesis (Hoijer, 1982). While some provocative research (Brown, 1958) indicates that language does indeed affect reality, it remains generally accepted that changes in reality happen first and then become encoded in the language. In either case, language and culture are inseparably tied. At another level the closeness of language and culture is noted by N.P. van Wyk Louw (1959) regarding Afrikaans:

... The change of environment (from Europe to Africa) has shaped and fashioned the young, newly evolving language. It has caused new words, new images and new concepts to come into being; old words and concepts to be adapted and in many cases to disappear; every feature of the new world to be reflected within its scope....

While language change has indeed occurred based on environment-induced changes in culture, Afrikaans remains European at base and thus would seem to perpetuate generally a modified European world view. It would be illuminating to do a contrastive analysis of Afrikaans and an older African language in such a way that would compare world views as carried by language. Such a study might examine, for example, frequency of words and word types to see the relevant concepts; patterns of pronoun usage, to see how one conceptualizes self and others; and active-passive constructions, to see where responsibility for events is seen to lie.

The choice of one's mother tongue is clearly not made by the individual, but made for the individual by the community in which he or she grows up. Indeed it is in the process of communication with others that one's self develops. This powerful process has been studied in a now classic work by Meade (1934), and he laid the groundwork for much of subsequent understanding of language and the self. This process of communication happens nonverbally as well as verbally, with sounded language as by far the most important communication 
code. Only as one gradually takes control of one's life are there other choices, and these choices are still strongly influenced by some community in some way. This is not much of an issue for an individual in a monolingual area, but when the outer world is multilingual, the issues become strong and the need for language choice demands the definition of a language-shaped inner world as well.

The inner world of a multilingual person and its languages contrasts with the outer world and its languages in several ways. The inner world is one of psychological comfort. It is where I can relax, where I can be myself. My first language is the language of self-identity, as there is no self-identity without others; my language is me. When I hear others speak the language with me, I am validated. I feel important because others accept my language and in some deep way understand who I am. This validating effect may help explain why Afrikaans is still the medium of instruction in Namibia. The work of Fishman et al. (1971) reveals five language domains, which he defines as contexts that affect language choice, and three of the five domains, home, neighborhood, and religion tend to validate the inner world.

The inner world is close to one's deep emotions. A professor of psychology from Latvia who was fluent in several languages and had done his major career work in English reported that, while he was comfortable in several languages, he could not swear or use deeply emotional language effectively in any other language but his first (Draguns, 1974). There is a well-repeated story of an Israeli who, with Hebrew his mother tongue, was complimented on his command of his second language, being able to tell jokes with great success in English. He shook his head and replied, "Yes, but in English I say what I can. In Hebrew I say what I want." His theme is echoed in a different way by a college student in Soweto, South Africa, who lamented the fact that he had to learn English. His classmates turned to him and, after a thoughtful pause, said, "But you will have to pass exams and later teach in English, and anyway, it's a universal language." He nodded sadly, "I know all that. But I always fear making mistakes in English, and I don't feel so comfortable with it, and I just wish I could study and teach in my own mother tongue, where I know what I'm doing."

The domains of school and work in terms of Fishman et al. (1971), which bring contact with the larger society, relate more to the outer world of a multilingual person. Di Pietro (1987) discusses the relative degree of commitment an L2 learner chooses to make regarding integrating with the second culture, and he relates commitment to choice of level of fluency in the L2. This choice of fluency marks in some way the self that the individual projects to the outer world, though it is made for inner-world purposes of integrating or connecting one's self in a certain way to others in the L2. Language choices in the outer world, while showing dimensions of the inner world, also are in a larger sense pragmatic, even economic. For example, at some level the multilingual may 
ask such questions as: "What benefits are there for me to use this language in this situation? What cost is there? Is the cost worth the benefits?" The benefits may be access to people with decision-making power, to technology, to books, to education; it may be the ability to persuade others toward a goal. The price may include distance from the home group, extra time and effort, and the loss that comes with any change, for to gain something, something else must always be given up.

The inner world of a multilingual person is greatly expressed in the mother tongue, the language of WHO I AM. The outer world of a multilingual person is greatly expressed in a second or third language learned after age 5, the language of WHO I HAVE BECOME. This difference is exemplified in the story of two mother-tongue speakers of Afrikaans who, upon meeting each other in a business setting, spoke in Afrikaans to show their inner-world solidarity and then switched to English to show their outer-world sophistication.

Kirschner and Stephens (1987) reveal some inner-world workings in their study of 37 university students who were Spanish-English bilinguals in the US and who were taking a course in the theory of bilingualism. Such students, despite doing university-level work, lacked confidence in their command of both languages, and they felt that their code-switching was due to laziness or inadequacy. They were pleased to learn in the class that their code-switching and choice of language are strongly related to domain, and that other bilinguals as well had questioned themselves about their own linguistic competence. This study shows the validation such students experienced from their outer world, that of others in the course and of bilingualism theory, telling them they were fine. In fact, these students, being in university and many in language studies, found no difficulty functioning in two cultures, and even pointed out their bicultural advantage, being able to view the world from two distinct vantage points. Kirschner and Stephens wonder if problems would develop for them if they now had to function in only one of their cultures.

Let us turn now to the language experience in the United States to add perspective on the Southern African experience.

The use of English in the US is pervasive, though some claim that we speak American rather than English. There is no official national language policy, though around 20 states have made policy regulations. According to Grosjean (1982), 93\% of Americans are monolingual in English. Six percent are bilingual, and about $1 \%$ (most of whom are adults) do not know English at all. Yet $13 \%$ (or $15 \%$, according to Ruiz, 1988) come from homes where languages other than English are spoken, and most of these persons, two out of three, are not immigrants but were born in the USA (Grosjean, 1982). From these figures we can see that in the US people tend to lose their mother tongue to English. Bilingualism is not the norm at all; in fact, it functions as a transitional phase from monolingualism in one language to monolingualism in English (Grosjean, 
1982). This fact illustrates the principle that it is the language group with lesser power that must adapt, must become bilingual; the more powerful group does not need to bother.

To give a personal example, this is certainly the case in my own family. My grandfather immigrated to the United States from Central Europe to work in the steel mills in Pennsylvania. He sent for his childhood sweetheart, my grandmother, and they raised six children who spoke Slovenian at home and went to school in English. The family saw English and, with it, an education as the way for their children to have a better life than the immigrant parents did. In the face of discrimination against other language speakers as well as embracing the promise of better economic opportunities, the children were quick not only to learn English but to forget Slovenian. The grandchildren at best picked up a handful of words (mainly for food!). In two generations we were all English monolinguals. My grandparents, by the way, never did learn much English.

The negative attitudes toward bilingualism in the US persist. Unless a person has perfect English and can hide his or her bilingualism, it is generally considered a problem rather than an asset (Kirschner and Stephens, 1987). Minority group members often accept this attitude themselves. In working once with a group of underemployed Spanish-speaking students in writing their resumés, I observed that not one in the class saw it as an extra capability that he or she could speak two languages. They knew it would go against them. Unfortunately bilingualism in the US tends to decrease prestige. Ruiz (1988) shows that bilingualism is generally considered by the American public to be un-American; pressure for assimilation is consistent and assimilation is what usually happens. "If people come here, let them learn English." Or "Let them go back to where they came from." Behind these attitudes one can often find fear, reported by McLaughlin in Grosjean (1982), more of other cultures than languages, in that the bilingual represents an alien way of thinking and alien values. This fear is all the more interesting because it seems exaggerated out of all proportion to any real influence on, let alone threat, to the American way of life. A study of the fear itself of cultural differences would be a useful undertaking for understanding the multilingual person in society.

These negative attitudes had softened in the decades of the sixties and seventies, only to be revived in the eighties to the extent that Congress is debating a proposed amendment to the United States Consitution requiring English to the exclusion of other languages. The assimilation metaphor of the melting pot is regaining ground lost to that of the multicultural salad bowl, where various cultures can keep at least some of their ethnic identity within the great American mix. Minority groups have worked hard to save their ethnic identity, the most successful according to Grosjean (1982) being the Navajos (Native Americans, formerly referred to as American Indians) and the 
Spanish-speaking, whose immigration both legal and illegal has increased in recent decades while that of other groups has slowed to a trickle. While the English Language Amendment is not expected to pass into law (Judd, 1987), the underlying attitudes of fear and hostility to foreigners constitute the real threat. According to Judd (1987), it is an example of the connection between language and politics as well as how tenuous the relationship is between education and ideology.

Bilingualism as it does exist in the US is quite diverse. Analysis of the 1980 census figures by Ruiz (1988) show that the largest second-language group speaks Spanish (15,5 million), followed by groups speaking French and German (3 million each), Italian (2,6 million), and Polish (1,3 million). Hundreds of other languages, including 300 Native American tongues, are spoken as well by smaller numbers of people.

The recent movement in the last two decades in the direction of bilingual education supported by federal funding has made it quite an issue. Bilingual education in the US has traditionally been conducted in private schools funded by parents who wanted their children educated in their own ethnic ways. On a personal note, when I was growing up, I went to the Irish Catholic school, my friend next door went to the Polish school, and my friend down the street went to the German school. Only the Polish school had classes in the L2, and only that school conducted classes in the medium of Polish. We three little girls felt not "quite as good as" our more Anglo friends in the mainstream public schools, but there were enough of us for it not to matter. With the advent of national public funding, however, a great amount of opposition to education in other languages surfaced. Bilingual education was established only after mandated by laws passed in 1968 (the Bilingual Education Act) upheld in 1974 by the US Supreme Court (Lau v Nichols), and reauthorized in 1978 and 1984 (Ruiz, 1988). Federal funds have been greatly reduced in recent years, though more effort is made at the state level. Bilingual education is offered in about 80 different languages, with the greatest concentration among Spanish-speaking children, who account for $80 \%$ of bilingual education programmes (Grosjean, 1982). Bilingual education programmes do not seek to develop either a bilingual person or a bilingual society, but are intended to serve as a means of Anglification for all (Ruiz, 1988). Two explanations for this situation are offered by Ruiz (1988), one based on hostility to linguistic pluralism, and a kinder one, "perhaps... a manifestation of our pragmatism: insuring English proficiency in these children empowers them in ways not afforded them by their own language" (p. 552).

The situation in the US brings out some very interesting similarities and differences with Southern Africa. In both places, English functions as a Language of Wider Communication (LWC). It also has a similar technological and economic role. In both places it is, for the most part, a way of advancement. People 
are threatened by differences, but the reactions are different because the realities are different. In the US people try to remove the threat by eradicating differences. In Southern Africa this strategy seems impossible, so a way must be found to accommodate differences. The challenge for both situations is for each to define appropriate ways that are both equitable and just.

Further juxtaposition of the two situations yields some intriguing paradoxes. In Southern Africa, many people want English and cannot get enough of it, in terms of instruction, materials, and qualified teachers, for example. In the US, many people do not want English only and yet are forced to function in it. In the US, mother tongues are discouraged and public funding for education in them is very hard to find; in Southern Africa, mother tongues are supported with public funding, even mandated. In the US, the attitude seems to be that people should forget their ethnic and linguistic origins and assimilate, become "American" in a very narrow sense of the word. In Southern Africa, the attitude seems that people should stay close to their origins and not assimilate.

The dominance of English in the States is firmly established, with the vast majority of the population mother-tongue speakers. In Southern Africa English as an L1 is not frequently found; in South Africa, for example, it is the L1 for only about $8 \%$ of the total population (Young, 1988). But English remains strong, he says, as a lingua franca and a medium of education. With growing voices in support of multilingualism (Cape Times Editorial 1988) the role of English may undergo some changes that are as yet unclear.

One cannot force a language on people by laws. Language choice can be made easier or more difficult, but if people have enough reasons to use a certain language, they will, regardless. If necessary, they will use language as resistance.

Such was the case with English in Soweto in 1976, where the attempt to make Afrikaans the medium of instruction in the schools sparked a protest which for additional reasons became the well-known Soweto riots. Such was the case as well with Afrikaans in 1822 and 1902, when British administrators did their best to suppress Afrikaans especially through imposing monolingual education in a foreign language, English. Not only did people resist; affronted in their inner world, they formed the nationalist identity around the language issue. Marais, quoted in Harrison (1981), stated: "Had it not been for (British administrator) Milner and his extreme measures, we Afrikaners would probably all quite happily have been speaking English by now. By his opposition to our language, he helped create it."

While the outer-world forces for language choice are strong, they are not absolute. As McLuhan (c. 1970) states, "There is no inevitability as long as there is a willingness to think." This is the whole purpose of education at its best, to free the energies of the human spirit and provide enabling skills for 
each person to make a creative contribution to the outer world. One must reclaim the power of self to transcend the limits of environment. Language choice is one way to do just that. People cannot wait for someone to hand them their personal, intellectual, and linguistic freedom. They must choose and go forward.

The power of the inner world of the multilingual should not be underestimated. To the extent that a multilingual can move in more than one language and culture group, he or she has access to a variety of inner and outer worlds. The little that is in each of us, when shared, can become enormous.

1 This paper is based on an invited lecture at the 1986 Seminar on Appropriate Education, Windhoek, Namibia, sponsored by Tucsin, at the University Centre for Studies in Namibia. Dr Puhl lectured as a specialist for the United States Information Service.

2 Though of course the concepts of "bilingual" and "multilingual" are not the same, for purposes of this paper they are used rather synonymously as aspects of a certain reality, namely that of a person living a significant part of life in a language additional to the mother tongue.

3 See Bokamba (1983) for a discussion of the cost of language policies in Africa.

\section{References}

BOKAMBA, E.G. 1983. The Africanization of English. In B.B. Kachru, The other tongue: English across cultures. Oxford: Pergamon Press.

BROWN, R. 1958. Words and things. New York: Free Press.

CAPE TIMES editorial. 1988. Multi-lingual South Africa. August 29.

DRAGUNS, J. 1974. Personal communication.

FISHMAN, J.A., R.L. Cooper, \& R. Ma. 1971. Bilingualism in the Barrio. Bloomington: Indiana University, Research Center for the Language Sciences.

GROSJEAN, F. 1982. Life with two languages. Cambridge, Massachusetts: Harvard University Press.

HARRISON, D. 1981. The white tribe of Africa: South Africa in perspective. Johannesburg: Macmillan South Africa. 
HOIJER, H. 1954. The Sapir-Whorf Hypothesis. In Samovar, L.A., and R.E. Porter, Intercultural communication: A reader. 1982. Belmont, Califomia: Wadsworth Publishing Company.

JUDD, E.L. 1987. The English Language Amendment: A case study on language and politics. In Tesol Quarterly, 21(1), 113-135.

KACHRU, B.B. 1983. The other tongue: English across cultures. Oxford Pergamon Press.

KIRSCHNER, C., \& T.M. Stephens. 1987. Bilingual theory and attitudinal change: The Spanish-English bilingual and the English-speaking L2 student of Spanish. In J.P. Lantolf and A. Labarca, eds., Research in second language learning: Focus on the classroom. Norwood, New Jersey: Ablex Publishing Corporation.

KOLERS, P.A. 1968. Bilingualism and information processing. Scientific American, 218(3), 78-86.

LOUW, N.P. VAN WYK. 1959. Let us not Extol. In Renewal in Prose, quoted in booklet The Afrikaans Language Monument. Paarl, South Africa.

MARTYNA, W. 1983. Beyond the he/man approach: The case for nonsexist language. In Language, gender and society, B. Thorne, C. Kramarae, and N. Henley, eds. Rowley, Massachusetts: Newbury House Publishers.

McLUHAN, M. c. 1970. The medium is the message. Film available at the Pennsylvania State University Media Center, University Park, Pennsylvania.

MEADE, G.H. 1934. Mind, self, and society. Chicago: The University of Chicago Press.

MILLER, C.M. \& K. Swift. Words and women. Garden City, New York: Doubleday.

PAULSTON, C.B.ed. 1988. International handbook of bilingualism and bilingual education. Westport, Conn.: Greenwoord Press, Inc.

RUIZ, R. 1988. Bilingualism and bilingual education in the United States in International handbook of bilingualism and bilingual education, C.B. Paulston, ed. Westport, Conn.: Greenwoord Press, Inc.

WEINREICH, W. 1974. Languages in contact. The Hague, 1953.

YOUNG, D. 1988. Bilingualism and bilingual education in a divided South African society. In International handbook of bilingualism and bilingual education, C.B. Paulston, ed. Westport, Conn.: Greenwoord Press, Inc. 